\title{
Niat beli ulang mahasiswa terhadap kopi berkonsep coffee-to-go shop
}

\author{
Nur Afifah Fibriyanti \\ Fakultas Ekonomi dan Bisnis Universitas YARSI \\ Jl. Let. Jend. Suprapto. Cempaka Putih, Jakarta Pusat, DKI Jakarta. Indonesia. 10510 \\ nurafifah.f12@gmail.com \\ La Diadhan Hukama* \\ Fakultas Ekonomi dan Bisnis Universitas YARSI \\ Jl. Let. Jend. Suprapto. Cempaka Putih, Jakarta Pusat, DKI Jakarta. Indonesia. 10510 \\ adhanhuk@gmail.com \\ *Penulis Korespondensi
}

Submitted: Apr 22, 2021; Reviewed: Apr 28, 2021; Accepted: May 20, 2021

\begin{abstract}
The competition for coffee shops in Indonesia is getting tighter, especially the coffee shop business with the coffee-to-go shop (take away) concept. The to-go coffee shop is a coffee shop that provides coffee drinks that are sold in packs that are ready to take (take away) so that they can be enjoyed in other places due to limited space. This study aims to analyze the effect of experiential marketing on repurchase intentions. The questionnaire in the study was distributed to 100 respondents with purposive sampling technique as a data collection technique. The findings in this study are that only the relate variable has a positive and significant effect on repurchase intention. Three other variables such as sensory, feel, and think have a positive but insignificant effect. While the act variable has a negative and insignificant effect. Thus, only a part of the experiential marketing dimension has an effect on the intention to repurchase students of the Faculty of Economics and Business, YARSI University.
\end{abstract}

Keywords: act; experiential marketing; feel; relate; repurchase intention; sensory; think

\begin{abstract}
Abstrak: Persaingan kedai kopi di Indonesia saat ini semakin ketat, khususnya bisnis kedai kopi dengan konsep coffee-to-go shop (take away). Kedai kopi to-go merupakan kedai kopi yang menyediakan minuman kopi yang dijual dalam kemasan yang siap bawa (take away) sehingga bisa dinikmati di tempat lain karena keterbatasan tempat. Penelitian ini bertujuan menganalisis pengaruh experiential marketing terhadap niat beli ulang. Kuesioner dalam penelitian disebar kepada 100 orang responden dengan teknik purposive sampling sebagai teknik pengumpulan data. Temuan dalam penelitian ini adalah hanya variabel relate yang berpengaruh positif dan signifikan terhadap niat beli ulang. Tiga variabel lainnya seperti sensory, feel, dan think berpengaruh positif namun tidak signifikan. Sedangkan variabel act berpengaruh negatif dan tidak signifikan. Dengan demikian, hanya sebagian dimensi experiential marketing yang berpengaruh terhadap niat beli ulang mahasiswa Fakultas Ekonomi dan Bisnis Universitas YARSI.
\end{abstract}

Kata kunci: act; experiential marketing; feel; niat beli ulang; relate; sensory; think 


\section{PENDAHULUAN}

Saat ini, salah satu minuman yang sedang digemari dan populer di semua kalangan, khususnya anak muda adalah kopi. Fenomena ini telah dimulai sejak era tahun 1985-an yang ditandai dengan banyaknya coffee shop atau kafe yang menyediakan produk kopi dalam bentuk ready to drink (RTD) yang diseduh dari kopi bubuk instan (dalam kemasan sachet). Masa tersebut disebut dengan gelombang pertama industri kedai kopi Indonesia (Toffin \& Mix, 2020).

Pada tahun 2001, Indonesia mulai memasuki gelombang kedua industri kedai kopi yang ditandai dengan terjadinya perubahan perilaku konsumen dalam meminum kopi. Perubahan tersebut adalah kebiasaan meminum kopi yang sebelumnya dianggap sebagai kebutuhan fungsional berubah menjadi kebutuhan emosional (Toffin \& Mix, 2020). Kebutuhan fungsional atau nilai fungsional terdiri dari harga yang dibayar, kualitas, dan kuantitas produk (Guerin, 2003; dalam Sudarso, 2016). Sedangkan kebutuhan emosional/ nilai emosional berasal dari manfaat yang dirasakan konsumen yang bersumber dari perasaan atau emosi positif. Perasaan tersebut muncul ketika konsumen mengonsumsi produk/ jasa (Sweeney \& Soutar, 2001; dalam Sudarso, 2016). Bagi sebagian masyarakat perkotaan, meminum kopi bukan hanya sekedar tuntutan selera namun telah menjadi menjadi bagian dari gaya hidup (Herlyana, 2012). Ketika seseorang minum kopi di kedai-kedai tertentu, dia terpersepsikan memiliki status sosial tertentu seperti status sosial atau gengsi yang meningkat. Hal tersebut sejalan dengan hasil survei Jakpat (2017) bahwa salah satu motivasi dasar konsumen mengonsumsi kopi adalah selain mengonsumsi kopi karena menyukai rasanya dan membantu tetap terjaga dengan kandungan kafein di dalamnya, mengonsumsi kopi dianggap sebagai bagian dari gaya hidup.

Saat ini, keberadaan kedai kopi diyakini sebagai tempat yang nyaman untuk berkumpul atau melakukan rapat, bahkan dijadikan sebagai tempat sarapan karena di tempat tersebut tersedia makanan yang siap dikonsumsi atau cepat saji. Masyarakat bisa menikmati kopi sambil beristirahat dan berbincang-bincang dengan rekan yang lain. Kebisaan tersebut yang diyakini telah menjadi salah satu gaya hidup bagi bagi masyarakat tertentu, sehingga tanpa ragu mereka menghabiskan uang dan mengisi waktu luang dengan meminum kopi di kedai-kedai kopi tertentu (Herlyana, 2012).

Selain terjadi pergeseran perilaku konsumen dalam mengonsumsi kopi, pada tahun 2016 terjadi diversifikasi bisnis kedai kopi yaitu kedai kopi yang berkonsep coffee-to-go shop (take away), yang mana sebelumnya konsep bisnis kedai kopi disebut kedai kopi artisan. Kedai kopi artisan adalah kedai yang menjual dan menyajikan kopi dengan cita rasa tinggi dengan aroma yang khas yang diseduh dengan teknik penyajian yang cermat, tidak terburu-buru, serta menggunakan bahan berkualitas dengan memprioritaskan suasana kafe sebagai (Toffin \& Mix, 2020; Wulandari, 2020). Sedangkan konsep coffee-to-go shop (take away) adalah kedai kopi yang masih menyediakan kursi, namun dengan jumlah terbatas atau tidak menyediakan tempat duduk dengan menjual kopi RTD yang berkualitas dengan harga yang lebih terjangkau, dikemas secara khusus sehingga kopi tersebut siap dibawa (ready to go) dan bisa dinikmati di tempat lain (Toffin \& Mix, 2020; Awaliyah \& Dwinanda, 2019). Kopi Kenangan, Janji Jiwa, Tuku, dan Fore dianggap sebagai pelopor kedai kopi berkonsep coffee-to-go shop (take away) atau kedai kopi to-go.

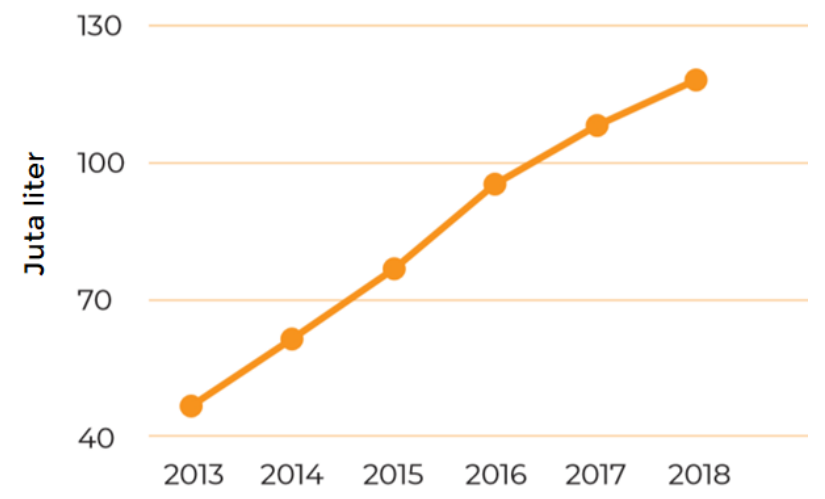

Gambar 1. Penjualan ritel kopi RTD di Indonesia pada tahun 2013-2018 (juta liter)

Sumber: Euromonitor passport (2019); dalam Toffin \& Mix (2020) 
Menurut riset Toffin \& Mix (2020), kedai kopi berkonsep coffee-to-go shop (take away) seperti Kopi Janji Jiwa, Kulo, Kenangan, dan lain sebagainya, banyak diminati oleh para pecinta kopi generasi milenial khususnya kalangan pemula kopi dari generasi Z (berusia 10-24 tahun) dan Y (berusia 25-39 tahun). Kedua generasi tersebut adalah kaum yang saat ini menguasai jumlah penduduk Indonesia. Tingginya minat kedua generasi tersebut khususnya minat mereka terhadap kedai kopi to-go, merupakan salah satu penyebab tingginya jumlah konsumsi kopi di Indonesia (Gambar 1). Seperti terlihat pada gambar tersebut, penjualan di Indonesia khususnya produk kopi RTD dalam enam tahun terakhir terus meningkat, yang mana pada tahun 2018 meningkat sampai mencapai 120 juta liter dan diperkirakan penjualan tersebut masih akan terus meningkat. Tingginya minat tersebut direspon oleh produsen dan pemasar kopi (pengusaha kedai kopi), baik pebisnis kedai lama dengan menambah jumlah kedai maupun pebisnis kedai kopi baru yang baru memulai usaha. Hal tersebut terlihat dari kedai kopi yang ada di mana-mana, mulai kedai kopi terkenal (misalnya Starbucks, Harvest, JCo, Dunkin Donut, Kopi Kenangan, Janji Jiwa, dan lain-lain) serta merek kepemilikan kecil perseorangan lainnya. Kedua fenomena tersebut telah menjadi salah satu pemicu tumbuhnya konsumsi kopi di Indonesia. Perkiraan laju pertumbuhan konsumsi tersebut mengindikasikan bahwa adanya ruang pasar baru yang besar dan dapat dimanfaatkan oleh para pebisnis kopi. Ruang pasar yang besar tersebut dapat menjadi peluang bagi pelaku bisnis kedai kopi, baik pebisnis lama maupun baru apabila disikapi dengan strategi pemasaran yang tepat. Apabila tidak disikapi dengan strategi pemasaran yang tepat, kemunculan kedai kopi baru akan menjadi ancaman bagi pebisnis lama.

Salah satu strategi pemasaran yang digunakan saat ini adalah konsep experiential marketing. Experiential marketing secara luas didefinisikan sebagai segala bentuk aktivitas/ kegiatan pemasaran yang berfokus pada pelanggan dalam rangka menciptakan hubungan dengan pelanggan (Schmitt, 1999). Salah satu tujuan dari experiential marketing adalah meningkatkan citra merek perusahaan. Saat ini, citra merek suatu perusahaan adalah salah satu aset terpenting yang tidak hanya membentuk keunggulan kompetitif, tetapi juga membantu perusahaan tetap berada di benak pelanggannya dan menghasilkan loyalitas pelanggan kepada perusahaan (Deheshti et al., 2016). Saat ini, konsep experiential marketing telah diperkenalkan secara luas ke banyak industri, seperti olahraga, rekreasi, dan pariwisata (Cuellar et al., 2015), restoran (Pratminingsih et al, 2018), bisnis ritel (Rosadi et al., 2019), maskapai penerbangan (Alagoz \& Ekici, 2014), layanan medis (Gheorghe et al., 2017), dan kedai kopi (Chang, 2020).

Dalam beberapa tahun terakhir, telah ada beberapa riset yang terkait bisnis kedai kopi dan experiential marketing. Terdapat temuan empiris menarik terhadap riset yang mayoritas respondennya didominasi oleh generasi $\mathrm{Z}$ yang berusia 10-24 tahun dan generasi yang berusia 25-39 tahun. Penelitian Chang (2020) dengan dominasi responden yang berusia di bawah 20 tahun, menemukan bahwa experiential marketing tidak dapat memengaruhi loyalitas pelanggan kedai kopi Starbucks di Taiwan. Temuan empiris menarik lain adalah hasil penelitian Setyono et al. (2017) dengan dominasi responden yang berusaia 17-25 tahun, menemukan bahwa hanya sense dan feel yang tidak berpengaruh terhadap niat beli ulang konsumen Konig Coffee \& Bar. Sedangkan temuan empiris lainnya, Febrini et al. (2019) dengan dominasi responden yang berusia 21-30, menemukan bahwa experiential marketing berpengaruh positif terhadap niat beli ulang di Warung Kopi Klotok.

Berdasarkan hasil riset Toffin \& Mix (2020), sejak tahun 2016 mulai terjadi peningkatan kedai kopi di Indonesia. Kedai kopi di Indonesia tahun 2019 berjumlah sekitar 2.950 gerai, jumlah tersebut mengalami kenaikan hampir tiga kali lipat dibanding tahun 2016 dengan jumlah kedai kopi sekitar 1.000 gerai. Seperti terlihat pada Tabel 1, dari tahun 2017 sampai tahun 2018, kedai kopi dengan konsep coffee-to-go shop pertama kali muncul di Indonesia yang langsung didominasi oleh kedai kopi merek Janji Jiwa dengan membuka 500 gerai, kemudian disusul kedai kopi merek Kulo sebanyak 300 gerai, dan Kopi Kenangan sebanyak 175 gerai.

Tabel 1. Jumlah kedai kopi konsep coffee-to-go shop Indonesia 2019

\begin{tabular}{llcc}
\hline No. & Kedai kopi & Mulai beroperasi & Jumlah outlet \\
\hline 1. & Kopi Kenangan & 2017 & 175 \\
2. & Kopi Soe & 2017 & 150 \\
3. & Fore & 2018 & 100 \\
4. & Janji Jiwa & 2018 & 500
\end{tabular}




\begin{tabular}{lll} 
5. Kulo & 2018 & 300 \\
\hline
\end{tabular}

Sumber: Toffin \& Mix (2020)

Bisnis kedai kopi, baik konsep kedai kopi artisan maupun kedai konsep coffee-to-go shop, adalah tergolong bisnis yang unik karena dalam bisnis tersebut memadukan antara usaha penyediaan barang (minuman kopi yang berkualitas) dan layanan jasa yang berkualitas secara bersamaan. Untuk menghasilkan minuman kopi yang berkualitas, pelaku bisnis kedai kopi akan memerhatikan seluruh aspek produksi. Dimulai dari pemilihan jenis kopi, proses sangrai/ roasting, proses penggilingan kopi, sampai pada proses penyeduhan kopi, serta bahan baku tambahan seperti susu dengan kualitas terbaik. Seluruh proses tersebut dilakukan secara seksama, cermat, dan tidak terburu-buru. Sedangkan dalam layanan jasa kedai kopi to-go menawarkan layanan yang berkualitas kepada konsumen. Layanan tersebut antara lain adalah adanya tawaran berbagai jenis varian rasa produk kopi susu, kemudahan dalam membeli (pesan lewat aplikasi), kemudahan dalam proses pengiriman kopi, serta kemudahan dalam pembayaran seperti menggunakan uang elektronik (Toffin \& Mix, 2020).

Ketika kinerja produk dan layanan yang diberikan oleh produsen melebihi harapan/ ekspektasi konsumen, maka konsumen akan merasa puas. Namun jika sebaliknya, kinerja produk dan layanan jauh dari ekspektasi maka konsumen akan merasa tidak puas. Kepuasan adalah perasaan senang atau kecewa seseorang yang dihasilkan dari membandingkan kinerja produk dengan harapan (Kotler \& Keller, 2016). Kepuasan pelanggan adalah anteseden penting dari loyalitas (Azoury et al., 2014). Loyalitas merupakan komitmen konsumen untuk membeli dan mengonsumsi kembali atau berlangganan kembali terhadap produk/ layanan yang disukai secara konsisten di masa depan, meskipun dipengaruhi oleh situasi tertentu atau upaya pemasaran yang berpotensi menyebabkan terjadinya perubahan perilaku (Oliver, 1997). Dampak positif dari kepuasan pelanggan salah satunya ditunjukkan dengan perilaku pembelian, niat pembelian kembali, word of mouth positif, retensi pelanggan, dan penggunaan secara terus menerus terhadap layanan diberikan oleh perusahaan (Anderson \& Sullivan, 1993; dalam Azoury et al., 2014). Pada tingkat kepuasan tertentu, konsumen akan memiliki kemauan yang kuat untuk melakuan pembelian ulang (Choi \& Kim, 2013).

Niat beli ulang (repurchase intention) merupakan perilaku konsumen yang direncanakan dalam pengambilan keputusan berdasarkan hasil evaluasi terhadap suatu produk atau jasa yang pernah dibelinya dengan kondisi konsumen yang memengaruhinya (Widjajanta et al., 2020). Niat beli ulang adalah perilaku pelanggan yang mana pelanggan memberikan respon secara positif terhadap apa yang telah diterima dari suatu perusahaan dan konsumen tersebut memiliki minat untuk berkunjung kembali atau membeli dan mengonsumsi kembali barang/ jasa perusahaan tersebut (Cronin \& Taylor, 1992).

Niat beli ulang merupakan salah satu faktor yang dapat memberikan pengaruh terhadap hubungan antara konsumen dengan perusahaan di masa depan, seperti keuntungan dan kesuksesan perusahaan (Nikbin et al., 2011). Konsumen yang setia, secara konsisten dapat berkontribusi terhadap pendapatan perusahaan yang bersumber dari meningkatnya pembelian ulang serta akan terjadi pengurangan biaya promosi sehingga dapat meningkatkan keutungan perusahaan (Li \& Green, 2011). Pembelian ulang dimungkinkan dengan membangun dan mengelola hubungan dengan pelanggan yang mana secara terusmenerus organisasi/ produsen menyesuaikan tawarannya sesuai dengan keinginan pelanggan serta memberikan nilai tambah dalam rangka meningkatkan kepuasan pelanggan (Varga et al., 2014).

Perusahaan selalu berusaha menjaga kualitas produk dan layanan yang diberikan agar pelanggan tetap memertahankan atau bahkan meningkatkan frekuensi pembeliannya. Grewal et al. (2008) merumuskan pengukuran niat beli ulang dengan empat indikator yang merupakan hasil modifikasi dari pengukuran niat beli ulang yang dirumuskan oleh Zeithaml et al. (1996). Indikator tersebut adalah (1) produk yang dikonsumsi dianggap sebagai pilihan utama di masa mendatang, (2) akan merekomendasikan produk tersebut kepada yang meminta saran, (3) akan merekomendasikan produk tersebut kepada teman, dan (4) akan mengonsumsi kembali produk tersebut di masa mendatang.

Perusahaan akan berusaha memberikan layanan yang berbeda dari pesaingnya. Layanan yang berbeda diharapkan dapat memberikan pengalaman yang berbeda terhadap konsumen dibandingkan dengan pesaingnya, dengan harapan dapat membentuk kesan positif yang tidak terlupakan. Salah satu konsep pemasaran yang dapat digunakan untuk memengaruhi sisi emosional konsumen dalam membeli sebuah produk atau jasa adalah melalui experiential marketing. Para pemilik usaha kedai kopi, selalu 
berusaha membentuk kesan positif yang tidak terlupakan di benak para konsumennya. Ada beberapa usaha yang dilakukan oleh pebisnis kedai kopi untuk memberikan pengalaman kepada konsumennya, antara lain menawarkan menu-menu kopi dengan nama yang unik seperti es kopi selingkuhan, es kopi mantan, es kopi kekasih, dan es kopi (Pasha, 2020). Selain itu, ada juga yang memberikan kebebasan kepada konsumennya untuk mencoba secara langsung bagaimana membuat segelas kopi secara manual atau menggunakan mesin dengan baik dan benar. Atau para pengunjung kedai kopi selain menikmati kopi, mereka dapat melihat seluruh proses pembuatan kopi. Tawaran yang lain adalah menawarkan kedai kopi dengan interior dan desain bagus atau instagramable. Ketika perusahaan berhasil menumbuhkan kesan positif dan kesan tersebut tidak terlupakan, sebenarnya hal tersebut sama dengan menumbuhkan pengalaman tertentu kepada konsumen. Ketika yang tersimpan di benak konsumen adalah ingatan positif yang dikarenakan dia puas, maka ada potensi konsumen tersebut menjadi loyal sehingga salah satu hal yang dilakukan adalah melakukan pembelian ulang.

Experiential berarti sebuah pengalaman yang berasal kata dari experience (Schmitt, 2009). Experience adalah ketika sensasi atau pengetahuan didapatkan oleh pelanggan yang diperoleh dari interaksi dengan berbagai unsur yang diciptakan oleh penyedia layanan (Nasermoadeli et al., 2013). Experiential marketing adalah suatu usaha yang dilakukan oleh para pemasar atau perusahaan, dalam mengemas produk/ jasa dengan menawarkan pengalaman emosi bahkan sampai kepada menggugah hati dan perasaan konsumen (Schmitt, 1999). Experiential marketing merupakan salah satu konsep pemasaran yang memiliki tujuan membentuk pelanggan yang loyal dengan cara menggugah emosi pelanggan yang terwujud melalui pengalaman-pengalaman positif dan suatu emosi yang positif terhadap jasa dan produk (Kertajaya, 2010; dalam Dewi et al., 2015). Sedangkan menurut Chandra (2008; dalam Huda \& Anisa, 2020) bahwa experiential marketing adalah merupakan salah satu strategi pemasaran yang dikemas dalam bentuk aktivitas tertentu, sehingga dapat memberi pengalaman positif dan sulit dilupakan oleh konsumen. Dengan demikian, tujuan akhir dari experiential marketing adalah menciptakan pengalaman positif dan sempurna dengan memberikan pengalaman yang mengesankan, menggugah hati, dan perasaan konsumen melalui kinerja produk dan jasa sehingga muncul keinginan untuk menggunakan produk dan jasa perusahaan tersebut secara terus menerus.

Ide utama strategi pemasaran berdasarkan pengalaman (experiential marketing) adalah menciptakan berbagai macam pengalaman positif bagi konsumen/ pelanggan. Rerangka dasar untuk mewujudkan pengalaman tersebut salah satu di antaranya adalah melalui konsep Strategic Experiential Moduls (SEMs). Strategic Experiential Moduls (SEMs) menguraikan lima jenis pengalaman konsumen/ pelanggan dan menjadi dasar dari experiential marketing meliputi pengalaman sense, feel, think, act, dan relate (Schmitt, 1999).

Sense marketing dititikberatkan pada perasaan pelanggan dengan tujuan untuk menciptakan pengalaman melalui panca indra. Sense marketing dapat dimanfaatkan oleh perusahaan melalui produk yang menjadi terdiferensiasi khususnya dengan produk saingannya, membuat konsumen semakin termotivasi dalam membeli produk dan jasa tanpa promosi yang intensif, serta berkontribusi dalam memberi menambah nilai produk/ jasa kepada pelanggan (Hestanto, 2008). Sense marketing bertujuan menciptakan kesan yang elegan dan menyenangkan melalui stimulan panca indra pelanggan sehingga konsumen merasa puas (Schmitt, 1999).

Titik berat feel marketing adalah usaha yang dilakukan dengan mengusahakan dan membangkitkan emosi konsumen agar terus merasa enak dan nyaman dengan produk/ jasa yang dikonsumsinya. Feel (pengalaman afektif) adalah hasil interaksi yang meningkat dan tumbuh sepanjang waktu yang berkembang melalui perasaan terdalam dan emosi konsumen (Schmitt \& Roger, 2008). Pengusaha ingin mewujudkan konsumen yang memiliki kebanggaan dan prestise terhadap produk dan jasa yang ditawarkan sehingga memiliki loyalitas kuat. Produsen dapat mengelola perasaan konsumen melalui dua hal, yaitu suasana hati (moods) dan emosi (emotion) konsumen (Hestanto, 2008).

Titik berat think marketing adalah produsen menginginkan pelanggan dapat berpikir secara mendalam, sehingga memberikan pendapat yang positif terhadap produk dan jasa perusahaan (Hestanto, 2008). Think (pengalaman kognitif kreatif) adalah berusaha menggerakkan konsumen agar tertarik dan berpikir kreatif, sehingga perusahaan mendapatkan masukan dari konsumen melalui umpan balik yang diberikan oleh konsumen (Schmitt \& Roger, 2008). Ketika konsumen diberikan keleluasaan dalam 
berpikir kreatif dan memberikan umpan balik, maka umpan balik tersebut direspon oleh perusahaan dengan memodifikasi produk dan jasa sesuai dengan yang dibutuhkan oleh konsumen.

Titik berat act marketing adalah membentuk persepsi pelanggan melalui pengalaman tubuh fisik, pola perilaku, gaya hidup, dan interaksi dengan orang lain (Schmitt \& Roger, 2008). Sehingga persepsi yang terbentuk melalui pengalaman-pengalaman tersebut akan memengaruhi perilaku konsumen dalam membeli barang dan jasa atau menjadi konsumen yang loyal. Dengan act marketing, perusahaan dapat mendesain atau membuat barang dan jasa yang berkaitan dengan perilaku dan gaya hidup konsumen. Sehingga melalui barang dan jasa, konsumen dapat mengekspresikan gaya hidupnya.

Titik berat relate marketing adalah mempertemukan pelanggan secara personal dengan masyarakat atau budaya. Relate marketing terbentuk dari dampak sense, feel, think, dan act. Fokus utama relate marketing adalah terciptanya persepsi positif dan pengalaman positif dengan pelanggan. Relate marketing adalah suatu usaha membangun dan mewujudkan suatu komoditas pelanggan lewat komunikasi (Kartajaya, 2004; dalam Rahmi et al., 2018). Saat ini, konsumen kopi dengan mudah dapat menikmati minuman kopi yang berkualitas, namun hal lain yang lebih penting adalah membuat konsumen mengingat layanan yang didapatkan sejak memesan kopi sampai kopi tersebut dikonsumsi.

Uraian tersebut dapat terkonfirmasi melalui beberapa temuan empiris terdahulu, antara lain Yang \& $\mathrm{He}$ (2011) bahwa pengalaman pelanggan berperan penting terhadap niat membeli. Hal yang sama juga terkonfirmasi dari temuan empiris lain bahwa experiential marketing berpengaruh positif terhadap niat beli ulang (Liang et al., 2013; Lunnette \& Andreani, 2017). Sedangkan hasil penelitian Febrini et al. (2019); Bellinda et al. (2020); Muhammad \& Artanti (2016) menemukan bahwa kepuasan konsumen mampu memediasi pengaruh experiential marketing terhadap niat beli ulang. Hal yang sama juga ditemukan dalam penelitian Astari \& Pramudana (2016) bahwa experiential value mampu memediasi pengaruh experiential marketing terhadap niat beli ulang. Sedangkan hasil penelitian Zena \& Hadisumarto (2012) menemukan bahwa experiential marketing dapat memengaruhi tingkat kepuasan dan loyalitas konsumen.

Sedikit berbeda dengan temuan-temuan empiris sebelumnya, namun ada beberapa temuan lain yang mana hanya ada beberapa komponen experiential marketing yang berpengaruh terhadap niat beli ulang. Hendarsono \& Sugiharto (2013) menemukan bahwa komponen act tidak berpengaruh terhadap niat beli ulang. Sementara Sayuti \& Dewi (2015) menemukan bahwa feel, think, dan act tidak berpengaruh terhadap niat beli ulang. Hal yang sama seperti temuan empiris Suhono et al. (2020) bahwa act, think, feel, sense, dan relate tidak berpangaruh terhadap loyalitas pelanggan. Hasil temuan empiris Rosadi et al. (2019) menemukan bahwa komponen yang berpengaruh terhadap bahwa niat beli ulang adalah sense dan act. Sedangkan temuan empiris Setyono et al. (2017) menemukan hanya sense dan feel yang tidak berpengaruh terhadap niat beli ulang.

Permasalahan dan fenomena experiential marketing dan niat beli ulang kedai kopi to-go menarik untuk dikaji. Berdasarkan hasil kajian literatur, belum ada peneliti yang mengeksplorasi secara khusus fenomena tersebut secara khususnya bagi kelompok generasi Z (10-24 tahun) dan generasi Y (25-39 tahun) bagi mahasiswa Program S-1 yang tergolong dalam kedua generasi tersebut. Dengan demikian, rumusan hipotesis penelitian ini adalah terdapat pengaruh positif sense, feel, think, act, dan relate terhadap niat beli ulang kedai kopi to-go XYZ.

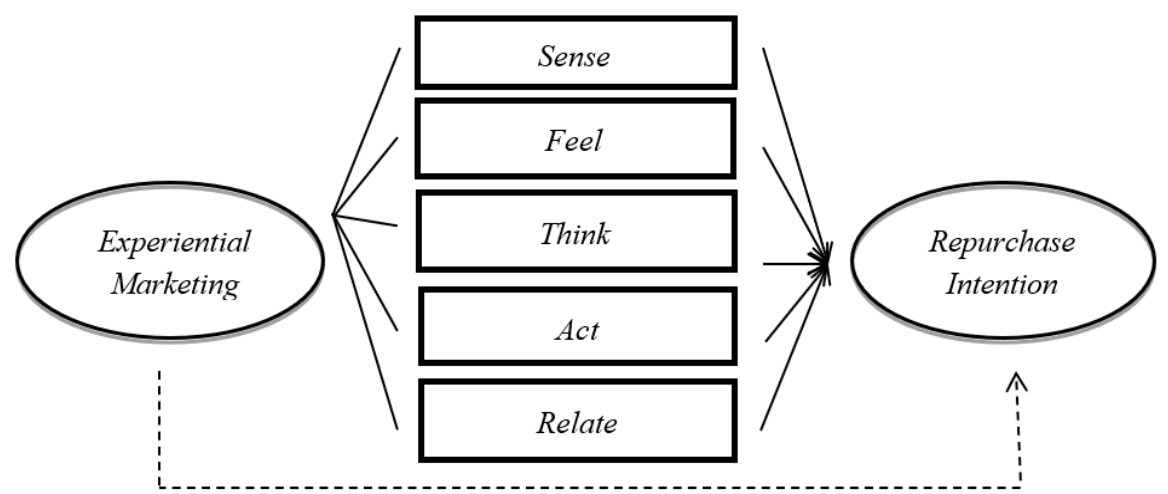

Gambar 2. Model penelitian

Sumber: Diolah dari berbagai sumber (2020)

190 


\section{METODE}

Penelitian ini menggunakan pendekatan kuantitatif. Target populasi dalam penelitian ini adalah mahasiswa FEB Universitas YARSI yang telah membeli dan mengonsumsi kopi kedai to-go XYZ. Mahasiswa FEB Universitas YARSI yang memenuhi kriteria populasi dan akan memiliki peluang/ kesempatan yang sama untuk terpilih sebagai sampel (Malhotra et al., 2017). Peneliti menetapkan kriteria/ syarat dalam pengambilan sampel, yaitu mahasiswa FEB YARSI yang minimal telah membeli dan mengonsumsi kopi kedai to-go XYZ. Dengan menentukan kriteria/ syarat tertentu, sehingga yang digunakan adalah teknik purposive sampling (Cooper \& Schindler, 2016).

Dalam penelitian ini, jumlah populasinya secara pasti tidak diketahui. Karena sifat tidak diketahui, dengan menggunakan rumus Lemeshow untuk menentukankan jumlah sampelnya (Levy \& Lemeshow, 1990). Penentuan jumlah sampel dalam penelitian ini menggunakan level kepercayaan $90 \%$, sehingga didapat jumlah sampel minimum sebesar 96 orang. Proses pengolahan dalam penelitian dibutuhkan minimal 30 sampel dan akan lebih baik jika jumlahnya semakin besar (Cohen et al., 2018). Sehingga dalam penelitian ini, jumlah sampelnya ditetapkan menjadi 100 sampel.

\section{HASIL DAN PEMBAHASAN}

Pengolahan instumen data dalam penelitian ini menggunakan program SPSS dan diperoleh hasil yang valid, karena nilai seluruh indikator memiliki nilai $r_{\text {hitung }}$ yang lebih besar dari 0,3.

Tabel 2. Hasil uji reliabilitas

\begin{tabular}{lcc}
\hline Variabel/ indikator & Cronbach's alpha $(\alpha)$ & Keterangan \\
\hline Sensory & 0,846 & Reliabel \\
Feel & 0,699 & Reliabel \\
Think & 0,845 & Reliabel \\
Act & 0,711 & Reliabel \\
Relate & 0,772 & Reliabel \\
Repurchase Intention & 0,795 & Reliabel \\
\hline
\end{tabular}

Sumber: Hasil pengolahan data (2020)

Dalam penelitian ini, digunakan uji reliabilitas dengan standar nilai Cronbach alpha $(\alpha)>0,6$. Berdasarkan hasil pengujian seperti terlihat pada Tabel 2, diketahui bahwa seluruh variabel/ indikator dinyatakan reliabel. Setelah didapat hasil uji validitas dan reliabilitas, selanjutnya dilakukan uji asumsi klasik yang terdiri dari uji normalitas, uji multikolinieritas, dan uji heteroskedastisitas. Data yang telah valid, reliabel, dan memenuhi syarat asumsi klasik, maka data selanjutnya dianalisis menggunakan regresi linier berganda.

Tabel 3 Hasil analisis regresi linier berganda

\begin{tabular}{lcccrc}
\hline \multirow{2}{*}{ Model } & \multicolumn{2}{c}{$\begin{array}{l}\text { Unstandardized } \\
\text { coefficients }\end{array}$} & $\begin{array}{c}\text { Standardized } \\
\text { coefficients }\end{array}$ & \multirow{2}{*}{$\mathrm{t}$} & \multirow{2}{*}{ Sig. } \\
\cline { 2 - 5 } & $\mathrm{B}$ & Std. Error & Beta & & \\
\hline (Constant) & 0,838 & 0,400 & & 2,095 & 0,039 \\
\hline Sensory & 0,179 & 0,129 & 0,171 & 1,387 & 0,169 \\
\hline Feel & 0,138 & 0,161 & 0,117 & 0,858 & 0,393 \\
\hline Think & 0,079 & 0,145 & 0,077 & 0,548 & 0,585 \\
\hline Act & $-0,120$ & 0,147 & $-0,114$ & $-0,814$ & 0,418 \\
\hline Relate & 0,498 & 0,117 & 0,469 & 4,240 & 0,000 \\
\hline
\end{tabular}

a. Dependent Variable: Repurchase Intention

Sumber: Hasil pengolahan data (2020) 
Dari hasil olah data pada Tabel 3, maka persamaan regresi sebagai berikut:

$\mathrm{Y}=0,838+0,179 \mathrm{X}_{1}+0,138 \mathrm{X}_{2}+0,079 \mathrm{X}_{3}-0,120 \mathrm{X}_{4}+0,498 \mathrm{X}_{5}+\mathrm{e}$

Berdasarkan ilustrasi pada Tabel 4, maka pengujian hipotesis penelitian ini didasarkan pada hasil pengujian terhadap pengaruh setiap variabel bebas terhadap variabel terikat.

Tabel 4. Pengujian hipotesis penelitian

\begin{tabular}{llll}
\hline Pengaruh & Sig. & Kriteria & Hasil \\
\hline Sensory Experience $\rightarrow$ Repurchase Intention & 0,169 & $<0,05$ & Tidak terbukti \\
Feel Experience $\rightarrow$ Repurchase Intention & 0,393 & $<0,05$ & Tidak terbukti \\
Think Experience $\rightarrow$ Repurchase Intention & 0,585 & $<0,05$ & Tidak terbukti \\
Act Experience $\rightarrow$ Repurchase Intention & 0,418 & $<0,05$ & Tidak terbukti \\
Relate Experience $\rightarrow$ Repurchase Intention & 0,000 & $<0,05$ & Terbukti \\
\hline Sut
\end{tabular}

Sumber: Hasil pengolahan SPSS (2020)

Berdasarkan hasil pengujian hipotesis penelitian di antara dimensi experiential marketing, salah satu variabel yang secara statistik berpengaruh positif dan signifikan adalah variabel relate memiliki nilai signifikan sebesar $0,000<0,05$. Dengan nilai tersebut, dapat diketahu bahwa hipotesis diterima. Sedangkan tiga dimensi yang lainnya, sensory, feel, dan think, berpengaruh positif namun tidak signifikan. Sedangkan satu variabel yang secara statistik berpengaruh negatif dan tidak signifikan, yaitu act. Hasil penelitian menyimpulkan bahwa tidak semua dimensi experiential marketing dapat menciptakan pengalaman bagi konsumen, khususnya mahasiswa FEB YARSI untuk melakukan pembelian ulang kopi kedai to-go XYZ.

Berdasarkan hasil pengolahan data seperti terlihat pada Tabel 3, diketahui bahwa nilai koefesien regresi variabel sensory experience terhadap repurchase intention bernilai positif, yaitu sebesar 0,179. Besarnya pengaruh tersebut berdasarkan hasil analisis, diduga bahwa beberapa mahasiswa FEB YARSI merasa kemasan kopi to-go XYZ belum menarik.

Berdasarkan Tabel 3, diketahui bahwa nilai koefesien regresi variabel feel terhadap repurchase intention bernilai positif, yaitu sebesar 0,138 . Besarnya pengaruh tersebut berdasarkan hasil analisis, diduga bahwa beberapa mahasiswa FEB YARSI merasa status sosialnya belum meningkat dengan membeli kopi di kedai to-go XYZ dan masih ada karyawan yang belum bersikap ramah dalam melayani pelanggan.

Berdasarkan Tabel 3, diketahui bahwa nilai koefesien regresi variabel think terhadap repurchase intention bernilai positif, yaitu sebesar 0,079. Besarnya pengaruh tersebut berdasarkan hasil analisis, diduga bahwa beberapa mahasiswa FEB YARSI merasa kopi kedai to-go XYZ belum memiliki citra positif di masyarakat.

Berdasarkan Tabel 3, diketahui bahwa nilai koefesien regresi variabel act terhadap repurchase intention bernilai negatif, yaitu sebesar -0,120. Besarnya pengaruh tersebut berdasarkan hasil analisis, diduga bahwa beberapa mahasiswa FEB YARSI merasa kopi kedai to-go XYZ belum menjadi bagian dari gaya hidup.

Berdasarkan hasil analisis regresi linear berganda seperti terlihat pada Tabel 3, diketahui bahwa nilai koefesien regresi variabel relate terhadap repurchase intention bernilai positif, yaitu sebesar 0,498. Besarnya pengaruh tersebut berdasarkan hasil analisis, diduga bahwa beberapa mahasiswa FEB YARSI mendapat informasi mengenai tentang kopi dari sesama pelanggan kopi kedai to-go XYZ dan ada kesan yang menyenangkan ketika berkumpul bersama teman atau keluarga di kedai kopi to-go XYZ.

Temuan empiris penelitian ini menunjukkan bahwa hanya dimensi relate yang signifikan berpengaruh terhadap repurchase intention. Relate secara signifikan berpengaruh terhadap repurchase intention kopi kedai to-go XYZ. Berdasarkan hasil analisis, diketahui bahwa beberapa responden mendapat informasi mengenai tentang kopi dari sesama pelanggan kopi kedai to-go XYZ dan ada kesan yang menyenangkan ketika mereka berkumpul bersama teman atau keluarga di kedai kopi to-go XYZ.

Beberapa dimensi lain, seperti sensory, feel, dan think, tidak signifikan dalam memengaruhi repurchase intention kopi kedai to-go XYZ. Berdasarkan hasil analisis, tidak signifikannya pengaruh dimensi tersebut antara lain disebabkan karena sebagian responden merasa bahwa kemasan kopi belum 
menarik, status sosial mereka belum meningkat dengan membeli kopi di kedai to-go XYZ, masih ada karyawan yang belum bersikap ramah dalam melayani pelanggan dan mereka merasa bahwa kedai togo XYZ belum memiliki citra positif di masyarakat.

\section{SIMPULAN DAN SARAN}

Berdasarkan hasil analisis data, di antara dimensi experiential marketing, salah satu variabel yang secara statistik, variabel relate berpengaruh positif dan signifikan terhadap repurchase intention. Tiga dimensi experiential marketing lainnya, sensory, feel, dan think berpengaruh positif namun tidak signifikan. Sedangkan satu variabel yang secara statistik berpengaruh negatif dan tidak signifikan positif, yaitu act. Hasil penelitian menyimpulkan bahwa tidak semua dimensi experiential marketing memiliki pengaruh terhadap niat beli ulang mahasiswa FEB YARSI.

Ada beberapa masukan atau saran bagi pemilik kedai kopi to-go XYZ dalam rangka meningkatkan niat beli ulang kopi kedai to-go XYZ (khususnya mahasiswa FEB YARSI), antara lain adalah mempertahankan kinerja relate serta mengoptimalkan kinerja sensory, feel, dan think. Dalam mengoptimalkan kinerja sensory, feel, dan think, ada beberapa saran yang dapat dipertimbangkan untuk dilakukan oleh manajemen kedai to-go XYZ, antara lain seperti memperbaiki kemasan kopi RTD, perlu merumuskan strategi yang tepat agar status sosial konsumen kopi bisa meningkat ketika konsumen mengonsumsi kopi to-go XYZ, serta strategi yang tepat dalam rangka meningkatkan citra kedai kopi togo XYZ di masyarakat.

Penelitian ini memiliki beberapa keterbatasan, antara lain adalah ruang lingkup populasi yang masih terbatas. Hal tersebut dapat menjadi saran penelitian selanjutnya dengan memperluas ruang lingkup populasi. Di samping itu, saran lain adalah memperkaya variabel-variabel lain yang masih terkait dengan experiential marketing dan niat beli ulang, seperti kepuasan pelanggan, persepsi nilai, persepsi kualitas, word of mouth, dan lain-lain.

\section{REFERENSI}

Alagoz, S. B., \& Ekici, N. (2014). Experiential marketing and vacation experience: The sample of Turkish Airlines. Procedia-Social and Behavioral Sciences, 150, 500-510. https://doi.org/10.1016/j.sbspro.2014.09.065

Astari, W. F., \& Pramudana, K. A. S. (2016). Peran experiential value dalam memediasi pengaruh experiential marketing terhadap repurchase intention. Jurnal Manajemen, Strategi Bisnis dan Kewirausahaan, 10(1), 16-30. https://ojs.unud.ac.id/index.php/jmbk/article/view/21486

Awaliyah, G., \& Dwinanda, R. (2019, 18 Desember). Ada tujuh jenis kedai kopi, mana yang jadi favorit milenial? https://gayahidup.republika.co.id/berita/q2opvz414/ada-tujuh-jenis-kedai-kopi-manayang-jadi-favorit-milenial

Azoury, N., Daou, L., \& El Khoury, C. (2014). University image and its relationship to student satisfaction - Case of the Middle Eastern private business schools. International Strategic Management Review, 2, 1-8. https://doi.org/10.1016/j.ism.2014.07.001

Bellinda, B., Dolorosa, E., \& Kurniati, D. (2020). Kepuasan dan loyalitas pelanggan Aming Coffee: Experiential marketing. Jurnal Bisnis dan Akuntansi, 22(2), 335-346. https://doi.org/10.34208/jba.v22i2.760

Chang, W. J. (2020). Experiential marketing, brand image, and brand loyalty: A case study of Starbucks. British Food Journal, 123(1), 209-223. https://doi.org/10.1108/BFJ-01-2020-0014

Choi, E. J., \& Kim, S. H. (2013). The study of the impact of perceived quality and value of social enterprises on customer satisfaction and re-purchase intention. International Journal of Smart Home, 7(1), 239-252. https://gvpress.com/journals/IJSH/vol7_no1/22.pdf

Cohen, L., Manion, L., \& Morrison K. (2018). Research methods in education. Routledge Taylor \& Francis E-Library

Cooper, D. R., \& Schindler, P. S. (2016). Business research methods. McGraw-Hill/ Irwin 
Cronin. Jr, J., \& Taylor, S. (1992). Measuring service quality - A reexamination and extension. The Journal of Marketing, 56, 55-68. https://doi.org/10.2307/1252296

Cuellar, S., Eyler, C., \& Fanti, R. (2015) Experiential marketing and long-term sales. Journal of Travel \& Tourism Marketing, 32(5), 534-553. https://doi.org/10.1080/10548408.2014.918925

Deheshti, M., Firouzjah, J. A., \& Alimohammadi, H. (2016). The relationship between brand image and brand trust in sporting goods consumers. Annals of Applied Sport Science, 4(3), 27-34. https://doi.org/10.18869/acadpub.aassjournal.4.3.27

Dewi, R. K., Kumadji, S., \& Mawardi M. K. (2015). Pengaruh experiential marketing terhadap kepuasan pelanggan dan dampaknya pada loyalitas pelanggan (Survei pada pelanggan tempat Wisata Jawa Timur Park 1 Kota Wisata Batu). Jurnal Administrasi Bisnis (JAB), 28(1), 1-6. https://administrasibisnis.studentjournal.ub.ac.id

Febrini, I. Y., Widowati, R., \& Anwar, M. (2019). Pengaruh experiential marketing terhadap kepuasan konsumen dan minat beli ulang di Warung Kopi Klotok, Kaliurang, Yogyakarta. Jurnal Manajemen Bisnis, 10(1), 35-54. http://journal.umy.ac.id/index.php/mb. doi:10.18196/mb.10167

Gheorghe, C., Gheorghe, I., \& Purcarea, V. (2017). Modeling the consumer's perception of experiential marketing in the Romanian private ophthalmologic services. Romanian Journal of Ophthalmology, 61(3), 219-228. https://pubmed.ncbi.nlm.nih.gov/29450402/ doi:10.22336/rjo.2017.40

Grewal, D., Roggeveen, A. L., \& Tsiros, M. (2008). The effect of compensation on repurchase intentions in service recovery. Journal of Retailing, 84(4), 424-434. https://doi.org/10.1016/j.jretai.2008.06.002

Hendarsono, G., \& Sugiharto, S. (2013). Analisa pengaruh experiential marketing terhadap minat beli ulang konsumen Cafe Buntos 99 Sidoarjo. Jurnal Manajemen Pemasaran, 1(2), 1-8. http://publication.petra.ac.id/index.php/manajemen-pemasaran/article/view/524

Herlyana, E. (2012). Fenomena coffee shop sebagai gejala gaya hidup baru kaum muda. Thaqãfiyyãt, 13(1), 187-204. http://ejournal.uin-suka.ac.id/adab/thaqafiyyat/article/view/43

Hestanto. (2008). Konsep experiential marketing. https://www.hestanto.web.id/niat-beli-purchaseintentions/

Huda, M., \& Anisa, F. (2020). The influence of experiential marketing, e-service quality (web-based tracking system) and trust on customer satisfaction in J\&T express service users in Kab. Pasuruan. Primanomics: Jurnal Ekonomi dan Bisnis, 18(1), 1-11. https://doi.org/10.31253/pe.v18i3.395

Jakpat. (2017). Segmentation survey: Motivation based coffee drinker - Survey report. https://blog.jakpat.net/segmentation-survey-motivation-based-coffee-drinker-survey-report

Kotler, P., \& Keller, K. L. (2016). Marketing management. Pearson Education Inc

Levy, P. S., \& Lemeshow, S. (1999). Sampling of populations: Methods and applications. WileyInterscience

Li, M. L., \& Green, R. D. (2011). A mediating influence on customer loyalty: The role of perceived value. Journal of Management and Marketing Research, 7, 1-12. http://www.aabri.com/manuscripts/10627.pdf

Liang, J. L., Chen, Y. Y., Duan, Y. S., Ni, J. J., \& Jinwen. (2013). Gender differences in the relationship between experiential marketing and purchase intention. The Journal of International Management Studies, 8(1), 10-19. http://www.jimsjournal.org/2\%20Liang,\%20Jin-Long.pdf

Lunnette, C., \& Andreani, F. (2017). Kepuasan experiential marketing terhadap minat beli ulang di Gyu Kaku Galaxy Mall. Jurnal Hospitality dan Manajemen Jasa, 5(2), 138-150. http://publication.petra.ac.id/index.php/manajemen-perhotelan/article/view/5946/5431

Malhotra, N. K., Nunan, D., \& Birks, D. F. (2017). Marketing research: An applied approach. PrenticeHall

Muhammad, M., \& Artanti, Y. (2016) The impact of experiential marketing on word of mouth (WOM) with customer satisfaction as the intervening variable. Jurnal Dinamika Manajemen, 7(2), 182-190. https://journal.unnes.ac.id/nju/index.php/jdm/article/view/8201/5619

Nasermoadeli, A., Ling, K. C., \& Maghnati, F. (2013). Evaluating the impacts of customer experience on purchase intention. International Journal of Business and Management, 8(6), 128-138. https://doi.org/10.5539/ijbm.v8n6p128 
Nikbin, D., Ismail, I., Marimuthu, M., \& Abu-Jarad, I. Y. (2011). The impact of firm reputation on customers' responses to service failure: The role of failure attributions. Business Strategy Series, 12(1), 19-29. https://doi.org/10.1108/17515631111106849

Oliver, R. L. (1997). Satisfaction: A behavioral perspective on the consumer. McGraw-Hill Education

Pasha, A. R. (2020, 4 Januari) Konsepnya unik, ini 6 kedai kopi paling hits di Indonesia versi Instagram. https://www.cermati.com/artikel/konsepnya-unik-ini-6-kedai-kopi-paling-hits-di-indonesia-versiinstagram

Pratminingsih, S. A., Astuty. E., \& Widyatami, K. (2018). Increasing customer loyalty of ethnic restaurant through experiential marketing and service quality. Journal of Entrepreneurship Education, 21(3). https://www.abacademies.org/journals/month-august-year-2018-vol-21-issue-3journal-ajee-past-issue.html

Rahmi, H. O., Budiarto, W., \& Indrawati, M. (2018) Pengaruh experiential marketing \& customer relationship management terhadap loyalitas pelanggan PT. PAL Indonesia (PERSERO). Jurnal Manajemen dan Administrasi Publik, 1(1), 1-14. https://doi.org/10.37507/map.v1i01.45

Rosadi, N., Suharyanti, \& Anitawati, M. T. (2019). Dampak experiential marketing terhadap minat beli $\begin{array}{lllll}\text { produk IKEA. Journal Communication Spectrum, } & 9(2), & \text { 176-188. }\end{array}$ https://doi.org/10.36782/jcs.v9i2.1986

Sayuti, M. H., \& Dewi, C. K. (2015). Analisis pengaruh customer experience terhadap minat beli ulang konsumen pada kafe Nom Nom Eatery Bandung. E-Proceeding of Management, 2(2), 1932-1940. https://openlibrary.telkomuniversity.ac.id/pustaka/files/101779/jurnal_eproc

Schmitt, B. H. (1999). Experiential marketing: How to get customers to sense, feel, think, act, relate to your company and brands. Free Press.

Schmitt, B. H., \& Rogers, D. L. (2008). Handbook on Brand and Experience Management. Edward Elga

Setyono, D., Widyanata, O. Y., Siaputra, H., \& Jokom, R. (2017). Analisa pengaruh experiential marketing terhadap minat beli ulang konsumen Konig Coffee \& Bar. Jurnal Hospitality dan Manajemen Jasa, 5(1). http://publication.petra.ac.id/index.php/manajemen-perhotelan/article/view/ 5268.

Sudarso, E. (2016) Kualitas layanan, nilai fungsional, nilai emosional, dan kepuasan konsumen: Sebuah studi kasus. Jurnal Ekonomi Bisnis dan Kewirausahaan, 5(3), 165-178. https://jurnal.untan.ac.id/index.php/JJ/article/view/19079/15961

Suhono, Hurriyati, R., \& Sultan, M. A. (2020). Analysis of the relationship between consumer-based brand equity, experiential marketing, customer satisfaction, and customer loyalty at Starbucks Coffee in Karawang. Jurnal Riset Bisnis, 4(1), 58-69. https://doi.org/10.35592/jrb.v4i1.1692

Toffin \& Mix. (2020). Brewing in Indonesia: Insights for successful coffee shop business

Varga, A., Dlacic, J., \& Vujicic, M. (2014). Repurchase intentions in a retail store - Exploring the impact of colours. Ekonomski Vjesnik, 27(2), 229-244. https://hrcak.srce.hr/file/196118

Widjajanta, B., Rahayu, A., \& Salsabila, A. (2020). Pengaruh perceived quality dan brand reputation terhadap repurchase intention pada reviewers Sepatu Bata aplikasi Shopee. Strategic, 20, 48-59. https://doi.org/10.17509/strategic.v20i1.27094

Wulandari, A. R. (2020, 26 April). Kopi artisan coba peruntungan di ranah daring. https://lokadata.id/artikel/kopi-artisan-coba-peruntungan-berjualan-online

Yang, Z. Y., \& He, L. Y. (2011). Goal, customer experience and purchase intention in a retail context in China: An empirical study. African Journal of Business Management, 5(16), 6738-6746. https://doi.org/10.5897/AJBM10.1287

Zeithaml, V. A., Berry, L. L., \& Parasuraman, A. (1996). The behavioral consequences of service quality. Journal of Marketing, 60, 31-47

Zena, P. A., \& Hadisumarto, A. D. (2012). The study of relationship among experiential marketing, service quality, customer satisfaction, and customer loyalty. Asean Marketing Journal, 4(1), 37-46. https://doi/org/10.21002/amj.v4i1.2030 
Jurnal Manajemen Maranatha — Vol. 20 Nomor 2, Mei (2021) 